\title{
INVESTIGATE STEADY-STATE HEAT AND MASS BALANCE FOR GREENHOUSES PAD-FAN COOLING SYSTEM
}

\author{
M. H. Hatem ${ }^{\mathrm{I}}$, K. M. Abdelbary ${ }^{\mathrm{II}}$ and K.M. Morsy ${ }^{\mathrm{III}}$
}

\begin{abstract}
This research work aims to investigate the steady-state heat and mass balance for greenhouses that use pad-fan cooling system. It also studies the evaporative cooling system efficiency in fiberglass modified Quonset greenhouse. Dry-bulb and wet-bulb temperature were measured, relative humidity and cooling efficiency were calculated and predicted dry-bulb temperature and relative humidity inside the greenhouse throughout the proposed simple model was performed. Dry-bulb temperature and relative humidity were homogeneous altitude along the fiberglass greenhouse under investigation (16 m long, average of fan air velocity was $5.23 \mathrm{~m} / \mathrm{s}$ and pad-face air velocity was $1.2 \mathrm{~m} / \mathrm{s}$ ). The obtained results showed that, the predicted data of dry-bulb temperature inside the greenhouse were validated well with that measured.
\end{abstract}

\section{INTRODUCTION}

$\mathrm{P}$ rotected cultivation of crops is a technology known as long ago. Large conservatories were a fashion among the wealthy during the nineteenth century. However, it has been revalued only during the past two or three decades that a large production has evolved which raises flowers, foliage plants, vegetables, and herbs out-of season in greenhouses Hasan, (1999).

Greenhouses are used in Egypt for producing different vegetables and Ornamental plants during varies seasons all over the year and are used as a nursery for producing different types of seedling Hasan, (1999).

I Prof. Agric. Eng. Dept., Fac. of Agric., Cairo Unvi.

II Assist. prof., Agric. Eng. Dept., Fac. of Agric., Cairo Unvi.

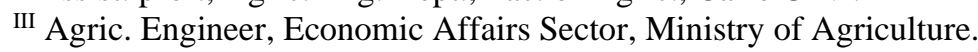


Greenhouses save many production plants for internal and external marketing such as flowers and vegetables.

The greenhouses are a lot of kinds division to single span contain (spherical dome, hyperbolic parabolic, Quonset, elliptical, modified Quonset, gothicarach, mansard roof, gable even span and gable uneven span) and double span contain (ridge and furrow, saw tooth). Most greenhouses are used in Egypt elliptical (modified Quonset) Hasan, (1999).

Many of glazing materials are used for covering greenhouses such as glass, polyethylene and fiberglass cover. Also using shading clothes is common in summer season to reduce the side effect of solar radiation.

Greenhouses are considered as an essentially solar collector in which plants are grown. During the winter, early spring and late fall, this characteristic is considered as an important system used for reducing the total heat energy needed to keep the greenhouse warm particularly during the cold day. During the summer, however, this becomes undesirable for growing plants, where the internal temperatures can quickly reach lethal levels. With inadequate cooling, excessive temperatures can significantly produced so that many farmers do not use the greenhouse in summer Hasan, (1999).

To increase greenhouses production efficiency, evaporative cooling systems are commonly used in summer months to decrease the internal temperature inside greenhouses and to increase its productivity. Evaporative cooling is the most efficient systems for greenhouses cooling, which can lower the inside air temperature significantly below the ambient air (Albright, 1990). The pad and fan system efficiency is usually given to be about $85 \%$ and under low humidity conditions $(<20$ $\%$ relative humidity); it is capable of cooling air more than $10^{\circ} \mathrm{C}$ below ambient temperature conditions Hanan, (1998).

Kittas et. al, (2003) calculated the temperature gradient along the greenhouse using proposed simple model which incorporates the effect of ventilation rate, roof shading and crop transpiration. Their measurements were performed in a commercial greenhouse equipped with fan-pad system and shaded in the second half. Their simulation model indicated 
the high ventilation rates and shading contribute to reduce the temperature gradients created by the fan-pad cooling system inside a greenhouse. However, they added some drawbacks. They found that increasing ventilation rate reduced temperature gradients but enhanced plant transpiration and could also, contribute to water stress stronger shading reduces the transpiration demand, but it proportionally reduce photosynthetic rate and, consequently, the expected yield. So, regulating the internal climate for optimum yield requires knowing the upper limits in terms of air temperature but also, the limits of plant transpiration rate in order to avoid stomatal ensure.

Montero and Anton, (1994) reported that four factors which permitted temperature reduction (such as ventilation or air renewal, crop evapotranspiration, shading, (Cover material) and water evaporation inside the greenhouse (fog system, cooling system, etc)).

Covering materials are considered separately from superstructures since almost any covering may be placed on almost any structure. The most common materials are: Glass, Acrylic (PMMA), Poly Carbonate (PC), Poly Vinyl Fluoride (PVF), Poly Vinyl Chloride (PVC), Fiberglass Reinforced Plastic (FRP), Poly Ethylene (PE) and Polyester Hanan, (1998).

Pollet and pieters, (2000 a) compared standard glass plate with ordinary polyethylene (PE) film as greenhouse cladding materials; they measured the radiation transmittance during a complete condensation cycle (dry phase; condensation without run-off; condensation with run-off; and evaporation phase). The transmittance was determined for three angles of incidence: 0,30 , and $60^{\circ}$. In the dry phase, at normal incidence, the transmittance of the ordinary PE film (about $90 \%$ was almost to the one of the standard glass plate (about $89 \%$ ). For increasing incidence angles, the transmittance of the PE film for the three angles of incidence was found to be $23 \%$ at normal incidence. They concluded that this transmittance decreased adopted an equilibrium value after approximately $1 \mathrm{hr}$ on the glass plate, however, the quick drop of transmittance was only observed for higher incidence angles. At normal incidence, the effect of condensate on the transmittance of the glass plate 
waks found to be insignificant. In most cases, the occurrence of run-off caused a slight change of the transmittance of both cladding materials with respect to the phase of condensation without run-off. As soon as the evaporation of the condensate started, the transmittance returned gradually to its original value for the dry state, In general, they stated that the effects of condensation on the radiation transmittance were greater on the PE film than the glass plate.

Pollet and pieters, $(2000 \mathrm{~b})$ investigated different covering materials of greenhouses such as: single glass, low-emissive glass, double glass, ordinary low-density polyethylene,(anti-drop-condensation polyethylene) and (anti-dust polyethylene). They studied also, the directionalhemispherical transmittances of the dry and the wet. They stated that under dry conditions, the directional-hemispherical transmittances of the three plastics films and the single glass plate coincided within $3 \%$ for incidence angles up to $60^{\circ}$. The directional- hemispherical transmittances of dry low-emissivity glass and especially dry double glass were significantly lower than the three plastic films and the single glass plate. They added also, depending on the cladding material and incidence angle, the effect of the presence of condensate on the directionalhemispherical transmittance was insignificant caused similar transmittance reductions for single and double glass reaching to the range of $13-15 \%$ at incidence angles ranged between $50^{\circ}-65^{\circ}$. The transmittance reductions determined for the wet low-emissivity glass were slightly smaller and limited to a maximum of $11 \%$ at an incidence angle of $70^{\circ}$. The addition of anti-drop agents to plastic films suppressed the transmittance reduction totally. They also found that, the different influences of the condensate on the transmittance of different cladding materials were mainly due to shape of the condensate drops, which were much flatter on glass than on non-anti-drop plastics. More over, assuming uniformly diffuse radiation, condensate was found to lower the hemispherical-transmittance by $8 \%$ for single and double glass, $5 \%$ for low-emissivity glass, $11 \%$ for low-density polyethylene and $13 \%$ for anti-dust polyethylene respectively. 
Reda, (2005) used Liquid Radiation Filter (LRF), single Poly Ethylene layer (PE) and double wall poly Carbonate $6 \mathrm{~mm}$ thickness (PC) as greenhouse covering materials. They concluded that the internal air temperature decreased during the daytime as compared with the outside air temperature, these decreases, at the peak day time, were 1.15, 2.02 and $4.61 \%$ with PE, PC and LRF. Also increases were obtained, during the night time, for the internal air temperature of the LRF greenhouse as compared with PE and PC. The percentages of this increase fluctuated between 1.25 to $7.63 \%$.

Kittas et. al, (2001) considered the ventilated greenhouse as a heat exchanger, the fans located on the wall opposite to the pads create a longitudinal fresh air flow through the greenhouse due to solar radiation incident on the canopy and the soil. They showed that heat losses through the cover o the outside limit this warming process, and for simplicity, the fraction of the incident solar radiation responsible for sensible heat transfer could be assumed to be fixed and equal to (1- $\alpha)$, where $\alpha$ is the fraction responsible for evapotranspiration. The heat balance, for a differential increment along the airflow, gave an equation for the internal greenhouse air temperature.

\section{MATERIAL AND METHODS}

In recent research, the performance of evaporative cooling system under fiberglass greenhouse conditions is investigated. These fiberglass greenhouses were located in Agricultural Research Center- Ministry of Agriculture on April 3, 9 and 102008 and July 9, 2008. Different climatic factors inside the greenhouse and outside the greenhouse were measured. These climatic factors include: dry-bulb, wet-bulb temperatures and air relative humidity. Various operating and design parameters for the system under investigation were measured and determined, such as air velocity, pad face velocity and prediction of inside temperature and relative humidity. 


\section{The Fiberglass Greenhouses}

Two fiberglass greenhouses (modified Quonset - corrugated polycarbonate) are used each having $16 \mathrm{~m}$ long, $6.40 \mathrm{~m}$ wide and $4.35 \mathrm{~m}$ high, as illustrated in fig. (1) and fig. (2). The cooling greenhouses were used for ornamental plants. That grows in containers. The cooling system is consisted of two extracting fans (single speed, belt driven, $0.6 \mathrm{~m}$ diameter, and $352 \mathrm{~m}^{3} / \mathrm{m}$ discharge) were located on the leeward side of each greenhouse and cross-fluted cellulose pads on the side toward the prevailing winds as shown in fig. (2). The cooling pads having a gross dimensions of $6.40 \mathrm{~m}$ wide, $2 \mathrm{~m}$ high and $10 \mathrm{~cm}$ thick. The Average fan air velocity was $5.23 \mathrm{~m} / \mathrm{s}$ and pad-face air velocity was $1.2 \mathrm{~m} / \mathrm{s}$. The cooling system was controlled by control unit. The pad was wetted by water supply from under ground tank. The water was flood above pads by a water pump with pulse 5 minute on and 25 minute off.

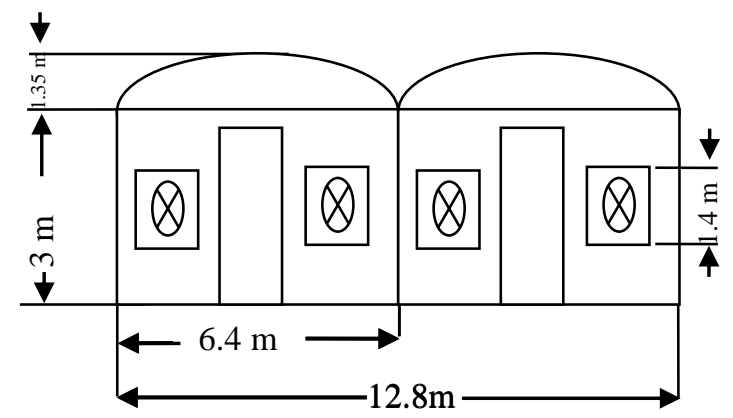

Fig. (1). Fiberglass greenhouses site (general site). 


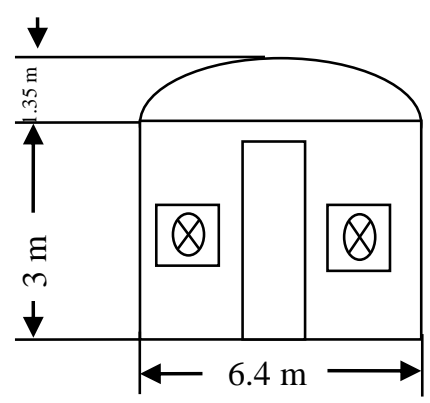

Elevation

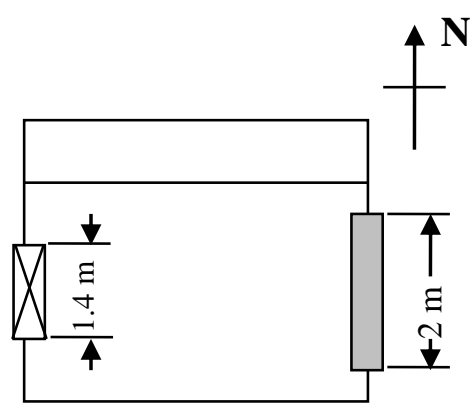

Side View

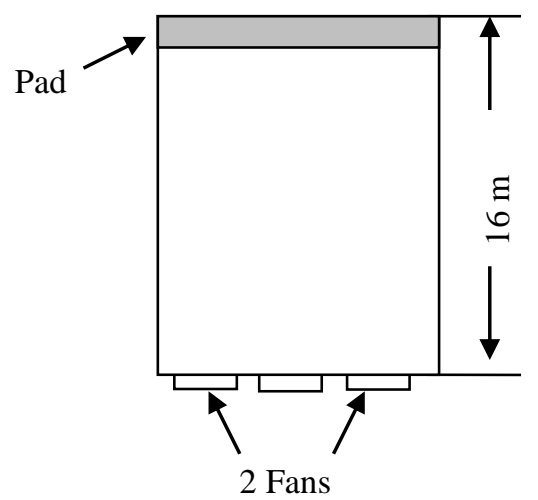

Plan

Fig. (2). Elevation, Plan and Side View of fiberglass greenhouse under investigation.

\section{Temperature Measurement}

The dry-bulb and wet-bulb temperature were measured by Ordinary thermometer (with range of -20 to $50{ }^{\circ} \mathrm{C}$ ) in 3 locations $(\mathrm{A}, \mathrm{B}, \mathrm{C})(\mathrm{A}$ at front of pad, $\mathrm{B}$ at the middle of greenhouse and $\mathrm{C}$ at the end of greenhouse (before fans)) at height of $1.5 \mathrm{~m}$ from the floor.

\section{Relative Humidity Calculating}

The air relative humidity (RH \%) was measured using Digital Tri-Sence (compound sensor that measured temperature, relative humidity and air velocity). Also it was calculated inside the greenhouse in three different locations using psychometric program. 


\section{Air Velocity Measurement}

Air velocity was measured in the greenhouse by the Digital Tri-Sence ((temperature, humidity and air velocity), Model No. 3700-0) in 5 different locations (in front of the fan and the pad, in first site, A, in meddle site, B and in the last site, C), Fig. (3).

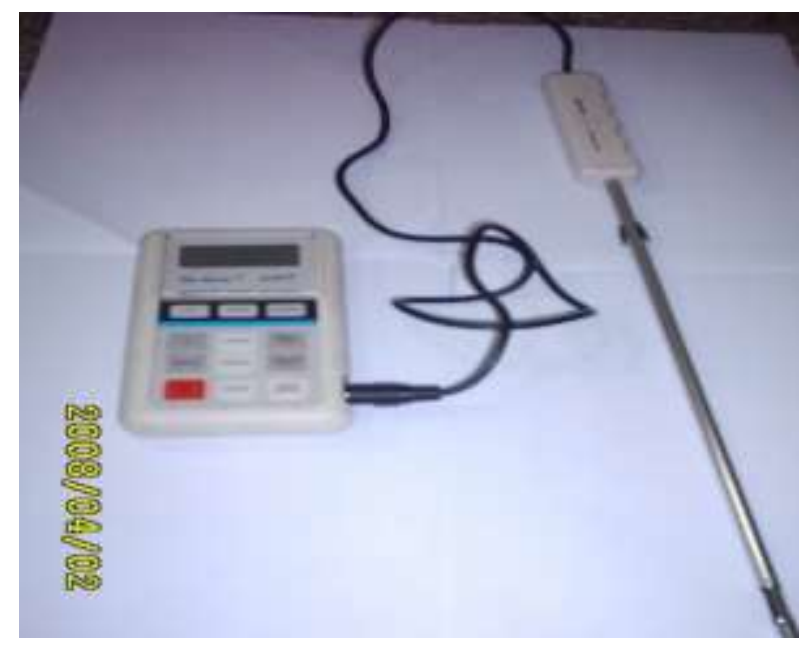

Fig. (3). Digital Tri- Sence, Model No. 3700-0.

\section{Cooling Efficiency Calculation}

Cooling efficiency was calculated using the following equation adapted by (ASHRAE, 1983):

$$
\eta=\frac{T_{d b}-T_{c d b}}{T_{d b}-T_{w b}} \times 100
$$

Where:

$\eta \quad$ Evaporative cooling efficiency, (\%).

$\mathrm{T}_{\mathrm{db}} \quad$ Dry-bulb temperature of outside air, $\left({ }^{\circ} \mathrm{C}\right)$.

$\mathrm{Tc}_{\mathrm{db}}$ Dry-bulb temperature of cooled air exiting the pads, $\left({ }^{\circ} \mathrm{C}\right)$.

$\mathrm{T}_{\mathrm{wb}} \quad$ Wet-bulb temperature of outside air, $\left({ }^{\circ} \mathrm{C}\right)$. 


\section{Dry-bulb Temperature Prediction}

The dry-bulb temperature was performed using the analysis of heat balance component inside the greenhouse with take into consideration all variable which affect evaporative cooling process.

$$
\text { Gains }- \text { losses }=\text { change in energy storage }
$$

Also, if conditions are steady-state, Fig. (4), there is no change in energy storage, the steady-state sensible energy balance rearranged in the form of:

$$
\text { Gains }=\text { Losses }
$$

And general energy balance can be written as the following:

$$
\mathrm{q}_{\mathrm{s}}+\mathrm{q}_{\mathrm{m}}+\mathrm{q}_{\mathrm{so}}+\mathrm{q}_{\mathrm{h}}+\mathrm{q}_{\mathrm{vi}}=\mathrm{q}_{\mathrm{w}}+\mathrm{q}_{\mathrm{f}}+\mathrm{q}_{\mathrm{e}}+\mathrm{q}_{\mathrm{vo}}
$$

Where:

qs Sensible heat gain within the airspace,(W).

qm Sensible heat gain from mechanical sources such as motors and light, (W).

qso Sensible heat gain from the sun, (W).

qh Sensible heat gain from a heating system, (W).

$\mathbf{q}_{\mathbf{v i}}$ The sensible heat contained in the ventilation air entering the space, (W).

qw The transfer on sensible heat through the structural cover of the building (walls, ceiling, windows, doors, etc.), (W).

qf Sensible heat transfer to the floor, (W).

qe The rate of conversion of sensible heat to latent heat within the airspace, (W).

qvo The sensible heat contained in the ventilation air leaving the space (referenced to the same temperature datum as $\mathrm{q}_{\mathrm{vi}}$ ), (W). 


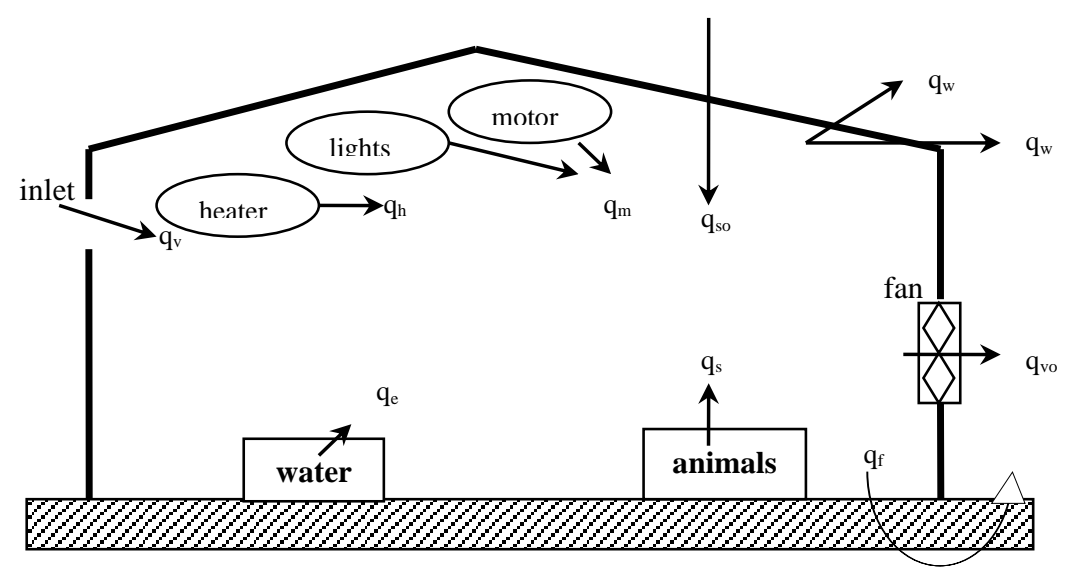

Fig. (4). Contributors to a sensible energy balance in agricultural building, Adapted by Albright, (1990).

According to Kittas et. al, (2001) and using equation (2)

$$
V \rho C_{p a} d T_{i n}=\left\lfloor\tau(1-\alpha) R g-\beta P_{w s, i n} \mid L d x-K c l\left[T_{i n}(x)-T_{e x t}\right] d x\right.
$$

Where:

$4 \quad$ Greenhouse width (perpendicular to the airflow), (m).

Roof perimeter corresponding to the greenhouse width, (m).

$V \quad$ Ventilation rate, $\left(\mathrm{m}^{3} / \mathrm{h}\right)$.

$R g \quad$ Outside global solar radiation, $\left(\mathrm{W} / \mathrm{m}^{2}\right)$.

$P_{w s} \quad$ Water vapor saturation partial pressure, $(\mathrm{Pa})$.

$K c \quad$ Heat loss coefficient of the greenhouse cover, $\left(\mathrm{W} / \mathrm{m}^{2} \cdot \mathrm{K}\right)$.

$\beta \quad$ Characteristic coefficient of the crop, (-).

$x \quad$ The distance of predicted point, (m).

$\tau \quad$ Solar transmissivity of cover, (-).

$\rho \quad$ Air density, $\left(\mathrm{kg} / \mathrm{m}^{3}\right)$.

$C_{p a} \quad$ Specific heat of air, (J/kg.K).

$\alpha \quad$ Transpiration coefficient, (-). 
By integration of equation (2) will give the following expression of $\mathrm{T}_{\text {in }}$ prediction.

$$
T_{\text {in }}=\frac{X \tau(1-\alpha) R_{g} L-X \beta P_{w s, i n} L+X K_{c} l T_{e x t}}{V \rho C_{P a}+1 / 2 X^{2} K_{c} l} * 60
$$

\section{Sensible Heat}

Sensible heat is calculated from the following equation (Kittas et al, 2001):

$$
q_{\text {Sens,1sthalf }}=\frac{V}{A_{g}} \rho C_{p a}\left(T_{m}-T_{p}\right)
$$

For the transfer between the middle and the pad and;

$$
q_{\text {Sens,2st half }}=\frac{V}{A_{g}} \rho C_{p a}\left(T_{f}-T_{m}\right)
$$

\section{Mass Balance Equation}

General form of mass balance equation can be written as the follows:

$$
\mathrm{m}_{\mathrm{p}}+\mathrm{m}_{\mathrm{vi}}=\mathrm{m}_{\mathrm{vo}}
$$

\section{Where:}

$m_{p}$ The rate of water vapor that is produced within the space, $(\mathrm{kg} / \mathrm{s})$.

$\mathrm{m}_{\mathrm{vi}}$ The rate of water vapor that is carried into the airspace by ventilation air, $(\mathrm{kg} / \mathrm{s})$.

$\mathrm{m}_{\mathrm{v}}$ The rate of water vapor that carried out of the airspace by ventilation air, $(\mathrm{kg} / \mathrm{s})$.

The moisture content of entering air and expelled air can be calculated using the following forms:

$$
\begin{array}{ll}
\text { Entering Air } & m_{v i}=\rho_{0} \dot{v}_{0} w_{0} \\
\text { Expelled Air } & m_{v o}=\rho_{i} \dot{v}_{i} w_{i}
\end{array}
$$

Where: 
$\rho_{i}, \rho_{0} \quad$ Inside and outside air density, $\left(\mathrm{kg} / \mathrm{m}^{3}\right)$.

$v_{i}, v_{0} \quad$ Internal and external air flow rate, $\left(\mathrm{m}^{3} / \mathrm{s}\right)$.

$w_{i}, w_{0} \quad$ Internal and external humidity ratio, $(\mathrm{kg} / \mathrm{kg})$.

\section{RESULTS AND DISCUSSION}

Passing air through a wet porous material or pad is the more popular method of providing the air moisture contact as previously mentioned. The bad can be wetted by dripping water onto the upper edge of vertically mounted pads, by throwing or spraying water onto the surface face. From collection of experimental field data and applying the proposed model for prediction of internal greenhouse conditions, the following results were obtained.

Table (1) illustrates dry-bulb, wet-bulb temperature, relative humidity and evaporative pad cooling system efficiency throughout three locations inside the fiberglass greenhouses. Also the external conditions for the same parameters are illustrated in Table (1). From Table (1) dry-bulb temperature ranged between $18.5-23{ }^{\circ} \mathrm{C}$ at first site (Pad site), $20.3-24{ }^{\circ} \mathrm{C}$ for second site (Middle) and 20-24 ${ }^{\circ} \mathrm{C}$ for the last site (at Fan site) in cooled greenhouse and ranged between $23-30{ }^{\circ} \mathrm{C}$ at first site, $24.5-30{ }^{\circ} \mathrm{C}$ for second site (Middle) and $24-31{ }^{\circ} \mathrm{C}$ for the last site (at Fan site) in ventilated greenhouse. 
Table (1). Hourly average dry-bulb, wet-bulb temperature, relative humidity and pad cooling system efficiency for cooled and ventilated fiberglass greenhouses, April 3, 2008.

\begin{tabular}{|c|c|c|c|c|c|c|c|c|c|c|c|c|c|c|c|c|c|c|c|c|c|c|c|c|}
\hline \multirow{4}{*}{ Time } & \multicolumn{12}{|c|}{ Internal Conditions in cooled greenhouse } & \multicolumn{9}{|c|}{ Internal condition in ventilated greenhouse } & \multirow{2}{*}{\multicolumn{3}{|c|}{$\begin{array}{l}\text { External } \\
\text { Conditions }\end{array}$}} \\
\hline & \multicolumn{4}{|c|}{ (Pad) First site } & \multicolumn{4}{|c|}{ Middle site } & \multicolumn{4}{|c|}{ (Fan) Last site } & \multicolumn{3}{|c|}{ (Pad ) First site } & \multicolumn{3}{|c|}{ Middle site } & \multicolumn{3}{|c|}{ (Fan) Last site } & & & \\
\hline & $\mathbf{T}_{\mathbf{d}}$ & $\mathbf{T}_{\mathbf{w}}$ & RH & $\eta$ & $\mathbf{T}_{\mathbf{d}}$ & $\mathbf{T}_{\mathbf{w}}$ & RH & $\eta$ & $\mathbf{T}_{\mathbf{d}}$ & $\mathbf{T}_{\mathbf{w}}$ & RH & $\eta$ & $\mathbf{T}_{\mathbf{d}}$ & $\mathbf{T}_{\mathbf{w}}$ & RH & $\mathbf{T}_{\mathbf{d}}$ & $\mathbf{T}_{\mathbf{w}}$ & RH & $\mathbf{T}_{\mathbf{d}}$ & $\mathbf{T}_{\mathbf{w}}$ & RH & $\mathbf{T}_{\mathbf{d}}$ & $\mathbf{T}_{\mathbf{w}}$ & RH \\
\hline & ${ }^{\circ} \mathbf{C}$ & ${ }^{\circ} \mathbf{C}$ & $\%$ & $\%$ & ${ }^{\circ} \mathbf{C}$ & ${ }^{\circ} \mathbf{C}$ & $\%$ & $\%$ & ${ }^{\circ} \mathbf{C}$ & ${ }^{\circ} \mathbf{C}$ & $\%$ & $\%$ & ${ }^{\circ} \mathbf{C}$ & ${ }^{\circ} \mathbf{C}$ & $\%$ & ${ }^{\circ} \mathbf{C}$ & ${ }^{\circ} \mathbf{C}$ & $\%$ & ${ }^{\circ} \mathbf{C}$ & ${ }^{\circ} \mathbf{C}$ & $\%$ & ${ }^{\circ} \mathbf{C}$ & ${ }^{\circ} \mathbf{C}$ & $\%$ \\
\hline *9a.m & 23.5 & 20 & 73 & - & 24 & 18 & 56 & - & 25 & 18 & 56 & - & 23 & 20 & 76 & 24.5 & 21 & 73 & 24 & 19 & 63 & 24 & 18 & 56 \\
\hline 10a.m & 23 & 20 & 76 & 75 & 21.5 & 18.5 & 75.4 & 88 & 23 & 20 & 76.2 & 75 & 24 & 22 & 84 & 25 & 22.5 & 81 & 23 & 24 & 84 & 32 & 20 & 32.7 \\
\hline 11a.m & 19 & 18 & 91 & 93 & 20.5 & 17 & 70.9 & 83 & 21 & 20 & 91.4 & 80 & 26 & 22 & 71 & 26.5 & 22 & 68 & 26 & 22 & 71 & 33 & 18 & 21.5 \\
\hline 12a.m & 19 & 18 & 91 & 94 & 21 & 16.8 & 65.9 & 81 & 21 & 20 & 91.4 & 81 & 28 & 20 & 48 & 28 & 20.5 & 51 & 28 & 20 & 48 & 34 & 18 & 19.1 \\
\hline 1p.m & 19 & 19 & 91 & 90 & 21.5 & 17 & 64.1 & 74 & 22 & 19 & 75.7 & 71 & 30 & 18 & 30 & 30.5 & 20 & 38 & 30 & 19 & 35 & 33 & 18 & 21.5 \\
\hline 2p.m & 19 & 18 & 91 & 93 & 20.5 & 16 & 63.2 & 83 & 22 & 18 & 68 & 73 & 30 & 19 & 35 & 31 & 21 & 40 & 31 & 19 & 31 & 33 & 18 & 21.5 \\
\hline 3.pm & 19 & 18 & 91 & 93 & 20.5 & 16.5 & 67.0 & 82 & 21.5 & 19 & 79.3 & 75 & 29 & 19 & 39 & 29.5 & 20.5 & 44 & 29 & 19 & 39 & 32 & 18 & 24.2 \\
\hline 4p.m & 19 & 18.5 & 95 & 92 & 20.3 & 16.8 & 70.7 & 81 & 21 & 19.5 & 87.2 & 75 & 27 & 19 & 47 & 28.1 & 20 & 48 & 28 & 20 & 48 & 30 & 18 & 30.2 \\
\hline 5p.m & 18.5 & 18 & 95 & 86 & 20.5 & 18.5 & 82.9 & 68 & 20 & 19 & 91.2 & 73 & 25 & 18 & 51 & 25.5 & 19.5 & 57 & 25 & 19 & 57 & 28 & 17 & 32.2 \\
\hline
\end{tabular}

* Without cooling.

- Missed data. 
Fig. (5) illustrates the average dry-bulb temperatures inside and outside the cooled greenhouse and the ventilated greenhouse. The dry-bulb temperature decreased gradually starting from 11 a.m by operating cooling system. Until reached the lower value at 5 p.m. The same figure illustrates the increase of dry-bulb temperature in ventilated greenhouse than the cooled greenhouse.

Pad-cooling efficiency ranged between $75-93 \%$ at pad site, $68-88 \%$ at the middle site of the greenhouse and from $73-81 \%$ at the fan site.

These differences between internal dry-bulb temperature values and efficiency values were small due to the short distance of passing cooled air stream (the length of greenhouse, was $16 \mathrm{~m}$ ).

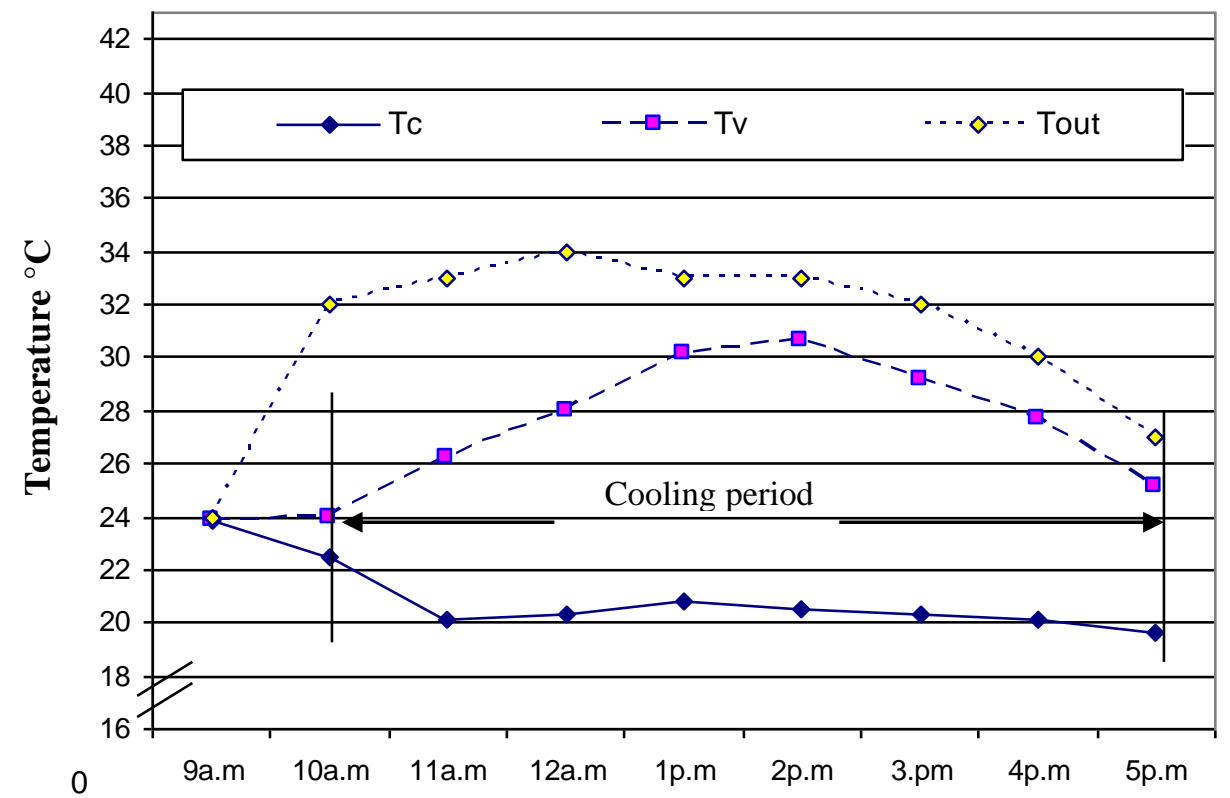

Time, h

Fig. (5). Internal average dry-bulb temperature in cooled and ventilated fiberglass greenhouses versus external dry-bulb temperature, April 3, 2008.

Fig. (6) illustrates internal condition through the second day of experiment. The cooling process started at $1 \mathrm{p} . \mathrm{m}$ due to decreasing in the 
external temperature. So that internal temperature increased gradually inside the greenhouse and once it reached to the set point temperature (23 ${ }^{\circ} \mathrm{C}$ ) cooling system start working. From the same figure it can noticed that increase ventilated greenhouse dry-bulb temperature than outside dry-bulb temperature at 9 a.m and 10 a.m due to the fan was off.

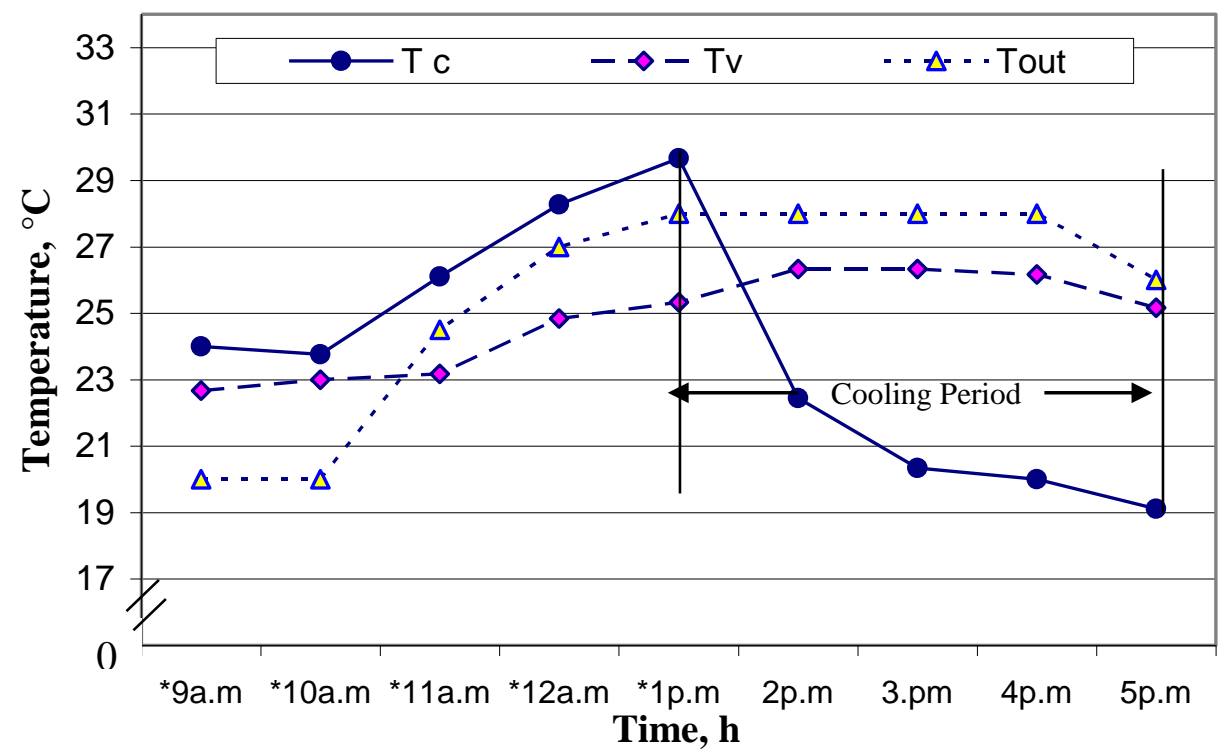

Fig. (6). Internal average dry-bulb temperature in cooled and ventilated fiberglass greenhouses versus external dry-bulb temperature, April 9, 2008.

Fig. (7) illustrates internal condition through the third day of experiment. The dry-bulb temperature increased gradually starting from 9 a.m to the afternoon period and reach to the minimum value of dry-bulb temperature at 5 p.m. 


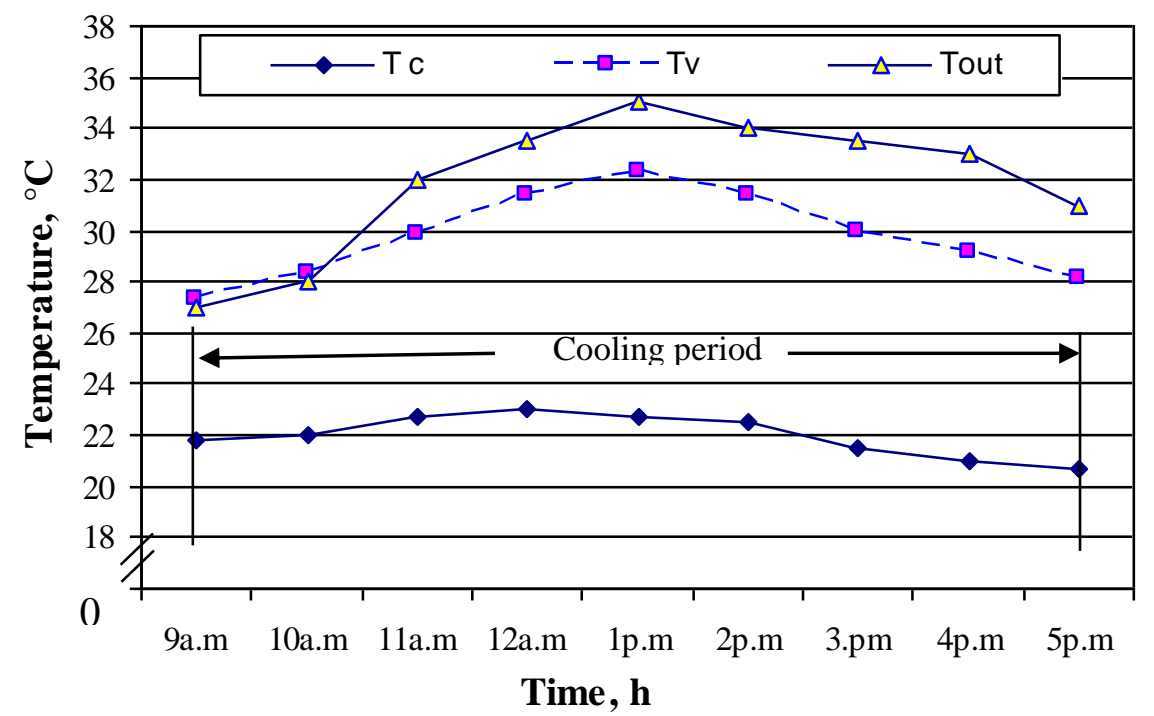

Fig. (7). Internal average dry-bulb temperature in cooled and ventilated fiberglass greenhouses versus external dry-bulb temperature, April 10, 2008.

Table (2) and fig. (8) show dry-bulb, wet-bulb temperature, relative humidity and evaporative pad cooling system efficiency throughout three different locations inside the cooled fiberglass greenhouse. Also the external conditions for the same parameters are illustrated in a hot day in July. From table (2) dry-bulb temperature ranged between $25-26.5^{\circ} \mathrm{C}$ at first site (Pad site), $25-28^{\circ} \mathrm{C}$ for second site (Middle) and $26-27^{\circ} \mathrm{C}$ for the last site (at Fan site). Pad-cooling efficiency ranged between 50 to $91.7 \%$ at pad site, $33.3-90.7 \%$ at the middle of the greenhouse and from $33.3-87.5 \%$ at the fan site. 
Table (2). Hourly average dry-bulb, wet-bulb temperature, relative humidity and pad cooling system efficiency for cooled Fiberglass greenhouse, July 9, 2008.

\begin{tabular}{|c|c|c|c|c|c|c|c|c|c|c|c|c|c|c|c|}
\hline \multirow{3}{*}{ Time } & \multicolumn{12}{|c|}{ Internal Conditions } & \multirow{2}{*}{\multicolumn{3}{|c|}{$\begin{array}{c}\text { External } \\
\text { Conditions }\end{array}$}} \\
\hline & \multicolumn{4}{|c|}{ (PAD) First Site } & \multicolumn{4}{|c|}{ Middle Site } & \multicolumn{4}{|c|}{ (FAN) Last Site } & & & \\
\hline & $\begin{array}{l}\mathbf{T}_{\mathbf{d}} \\
{ }^{\circ} \mathbf{C}\end{array}$ & $\begin{array}{l}\mathbf{T}_{\mathbf{w}} \\
{ }^{\circ} \mathbf{C}\end{array}$ & $\begin{array}{c}\mathbf{R H} \\
\%\end{array}$ & $\begin{array}{l}\eta \\
\%\end{array}$ & $\begin{array}{l}\mathbf{T}_{\mathbf{d}} \\
{ }^{\circ} \mathbf{C}\end{array}$ & $\begin{array}{l}\mathbf{T}_{\mathbf{w}} \\
{ }^{\circ} \mathbf{C}\end{array}$ & $\begin{array}{c}\mathbf{R H} \\
\%\end{array}$ & $\begin{array}{l}\eta \\
\%\end{array}$ & $\begin{array}{l}\mathbf{T}_{\mathbf{d}} \\
{ }^{\circ} \mathbf{C}\end{array}$ & $\begin{array}{l}\mathbf{T}_{\mathbf{w}} \\
{ }^{\circ} \mathbf{C}\end{array}$ & $\begin{array}{c}\mathbf{R H} \\
\%\end{array}$ & $\begin{array}{l}\eta \\
\%\end{array}$ & $\begin{array}{l}\mathbf{T}_{\mathbf{d}} \\
{ }^{\circ} \mathbf{C}\end{array}$ & $\begin{array}{l}\mathbf{T}_{\mathbf{w}} \\
{ }^{\circ} \mathbf{C}\end{array}$ & $\begin{array}{c}\mathbf{R H} \\
\%\end{array}$ \\
\hline 9a.m & 26 & 25.5 & 96.11 & 75.0 & 27 & 26 & 92.45 & 50.0 & 26 & 25 & 92.29 & 75.00 & 29 & 25 & 72.56 \\
\hline 10a.m & 26 & 25.5 & 96.11 & 50.0 & 27 & 26 & 92.45 & 33.3 & 27 & 25 & 85.18 & 33.33 & 29 & 23 & 60.35 \\
\hline 11a.m & 26.5 & 26 & 96.15 & 64.3 & 28 & 27 & 92.60 & 42.9 & 27 & 25.5 & 88.78 & 57.14 & 31 & 24 & 56.24 \\
\hline 12a.m & 26.5 & 24.5 & 96.03 & 81.3 & 26 & 25 & 92.00 & 87.5 & 26 & 24 & 84.88 & 87.50 & 33 & 25 & 52.59 \\
\hline 1p.m & 25 & 24.5 & 96.03 & 90.9 & 27 & 26 & 92.29 & 72.7 & 27 & 24 & 78.19 & 72.73 & 35 & 24 & 40.30 \\
\hline 2p.m & 26 & 25 & 92.29 & 84.6 & 26.5 & 25 & 88.67 & 80.8 & 27 & 24 & 78.19 & 76.92 & 37 & 24 & 34.04 \\
\hline 3.pm & 26 & 24 & 84.88 & 84.6 & 26.5 & 25.5 & 92.37 & 80.8 & 27 & 24 & 78.19 & 76.92 & 37 & 24 & 34.00 \\
\hline $4 \mathrm{p} . \mathrm{m}$ & 26 & 24 & 84.88 & 91.7 & 26 & 25 & 92.29 & 91.7 & 27 & 24 & 78.19 & 83.33 & 36.5 & 25 & 39.60 \\
\hline $5 \mathrm{p} . \mathrm{m}$ & 26 & 24 & 84.88 & 91.7 & 26 & 24.5 & 88.55 & 91.7 & 26.5 & 23 & 74.54 & 87.50 & 36 & 25 & 41.24 \\
\hline
\end{tabular}




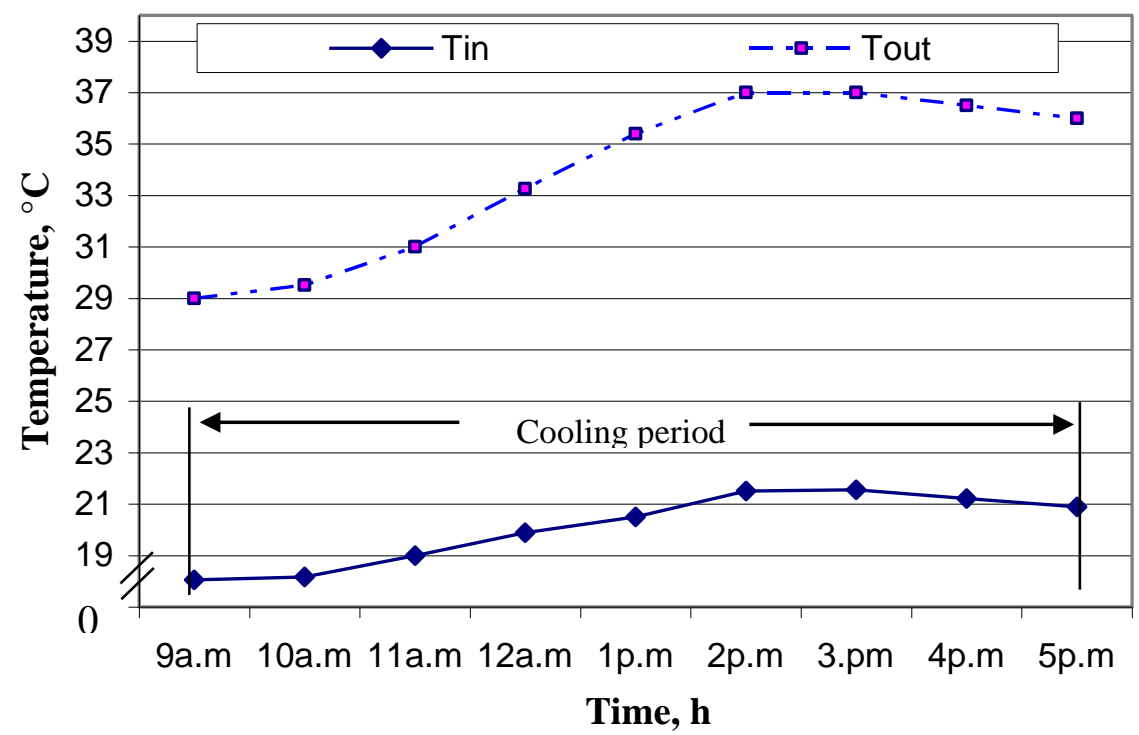

Fig. (8). Internal average dry-bulb temperature in cooled fiberglass greenhouse versus external dry-bulb temperature, July 9, 2008.

Figs. (9, 10, and 11) show the variation in air relative humidity values inside and outside two fiberglass greenhouses. From fig. (9) it can be noticed that the average air relative humidity increase in cooled greenhouse than ventilated greenhouse and outside condition, this increase was due to the effect of pad cooling system. It can be noticed the same behavior in fig. (11).

Fig. (10) illustrates the average air relative humidity through the second day of experiment. The cooling process started at 1 p.m due to decreasing in the external temperature. 


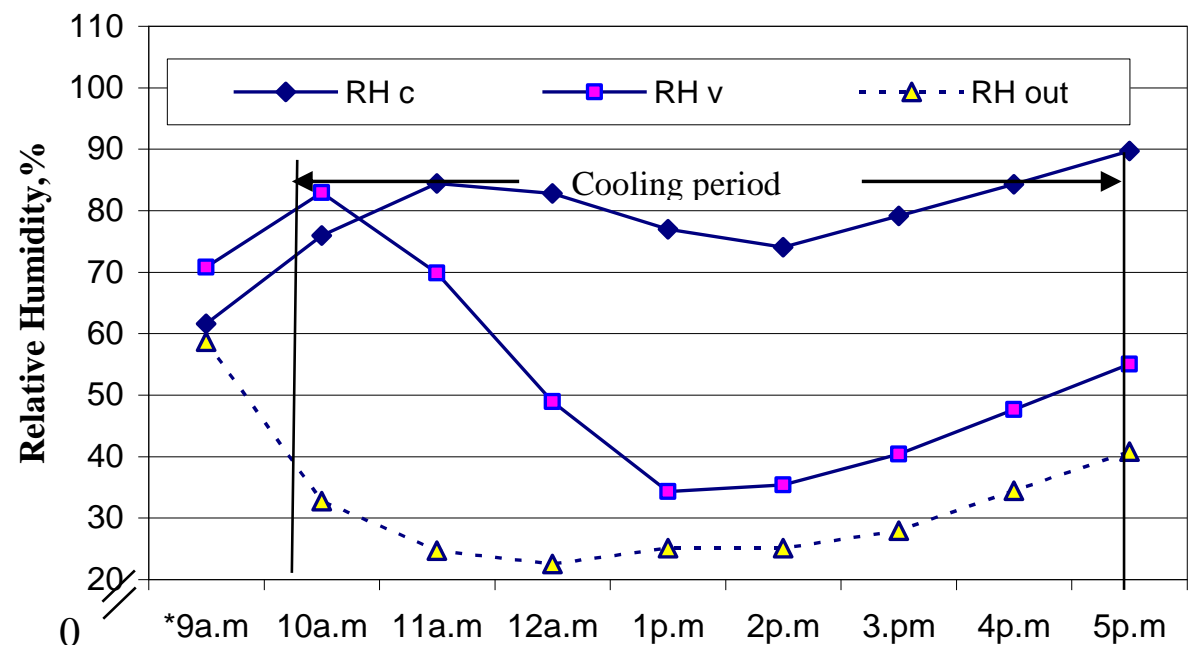

Time.h

Fig. (9). Internal average air relative humidity versus external relative humidity for cooled and ventilated fiberglass greenhouses, April 3, 2008.

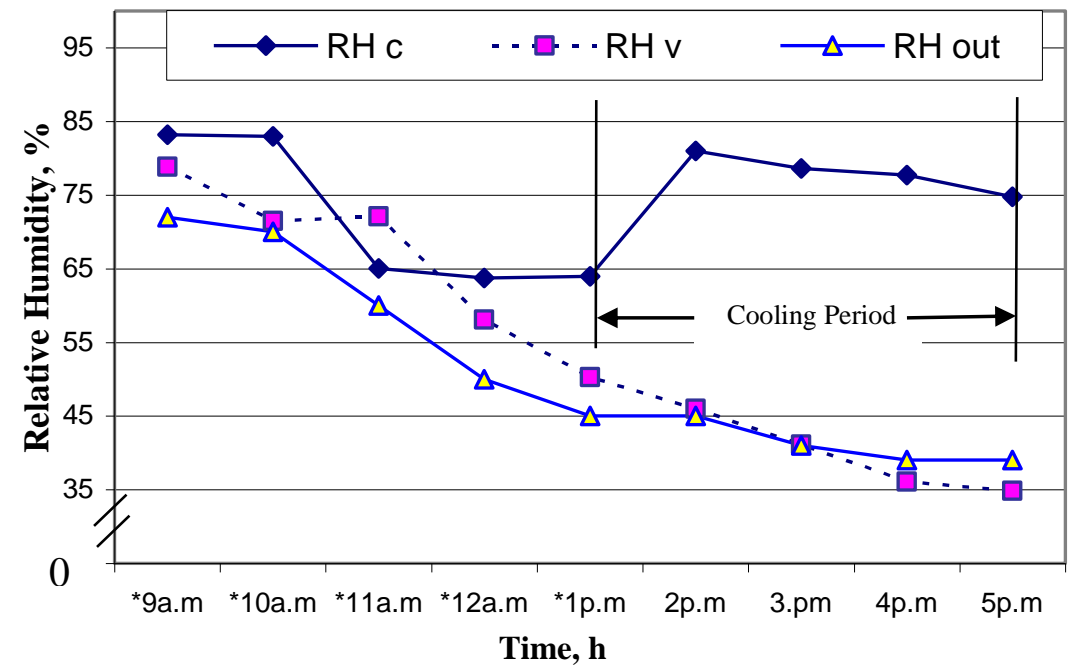

Fig. (10). Internal average air relative humidity versus external relative humidity for cooled and ventilated fiberglass greenhouses, April 9, 2008. 


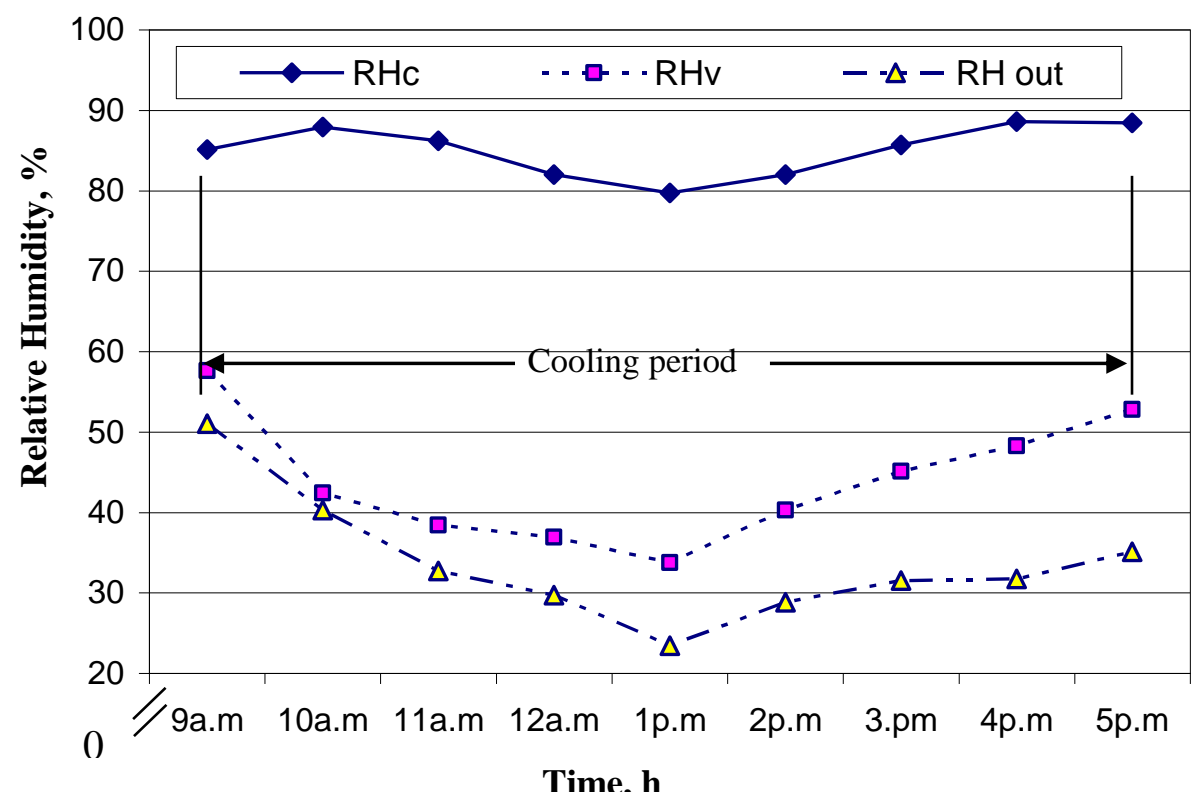

Fig. (11). Internal average air relative humidity versus external relative humidity for cooled and ventilated fiberglass greenhouses, April 10, 2008.

Fig. (12) shows the variation in air relative humidity values through three different locations inside and outside the cooled fiberglass greenhouses during the hottest day of July. The average air relative humidity inside the cooled fiberglass greenhouse was greater than the outside throughout the day light. 


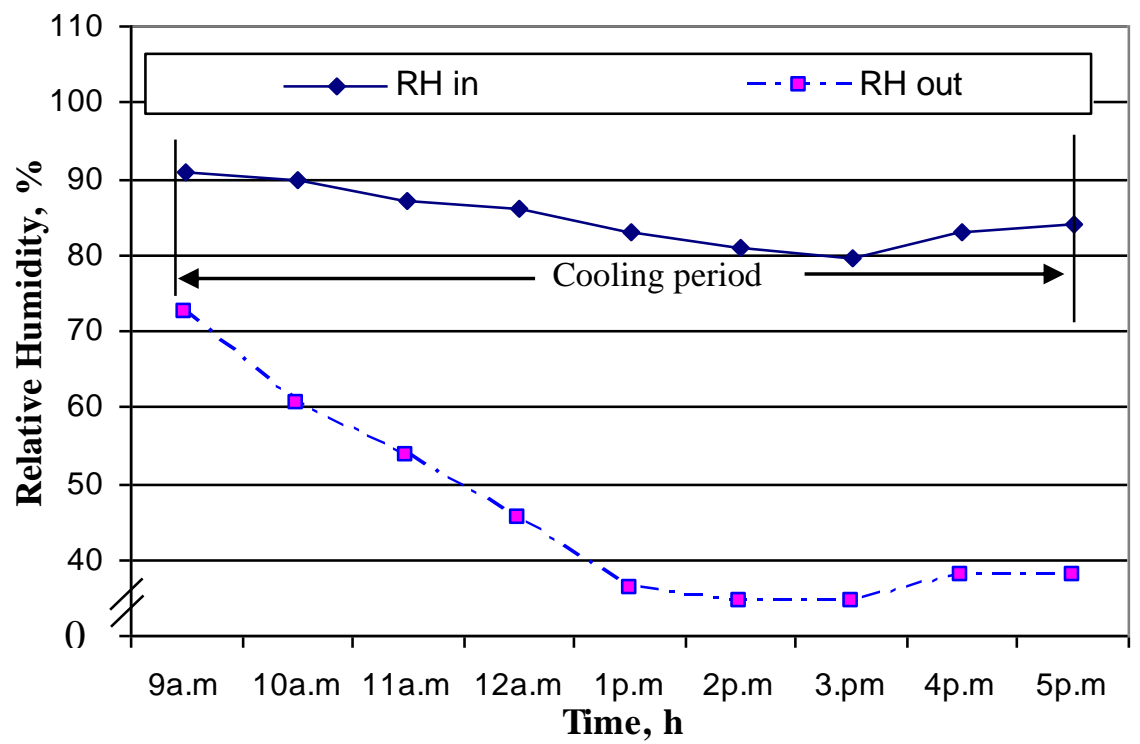

Fig. (12). Internal average air relative humidity versus external relative humidity for cooled fiberglass greenhouse, July 9, 2008.

Figs. $(13,14)$ illustrate the average of air flow rate at the three sites in the two greenhouses. Air flow rate ranged between $0.7-1.1 \mathrm{~m} / \mathrm{s}$ at first site, $0.8-0.9 \mathrm{~m} / \mathrm{s}$ at middle site and $0.8-1.2 \mathrm{~m} / \mathrm{s}$ at last site (fan site) for the ventilated greenhouse, also it ranged between $0.9-1.3 \mathrm{~m} / \mathrm{s}$ at pad site, $0.7-$ $1.1 \mathrm{~m} / \mathrm{s}$ at middle site $0.8-1.1 \mathrm{~m} / \mathrm{s}$ at last site (fan site) inside the cooled greenhouse.

Difference between air flow rates at three sites were slightly small and can be neglected due to shorter distance also the laminar flow of air inside the greenhouse can be noticed from this figure. This situation was applicable to investigate steady state analyses and modeling for inside environmental control. By applying of proposed model predicting of drybulb temperature and air relative humidity can be performed. 


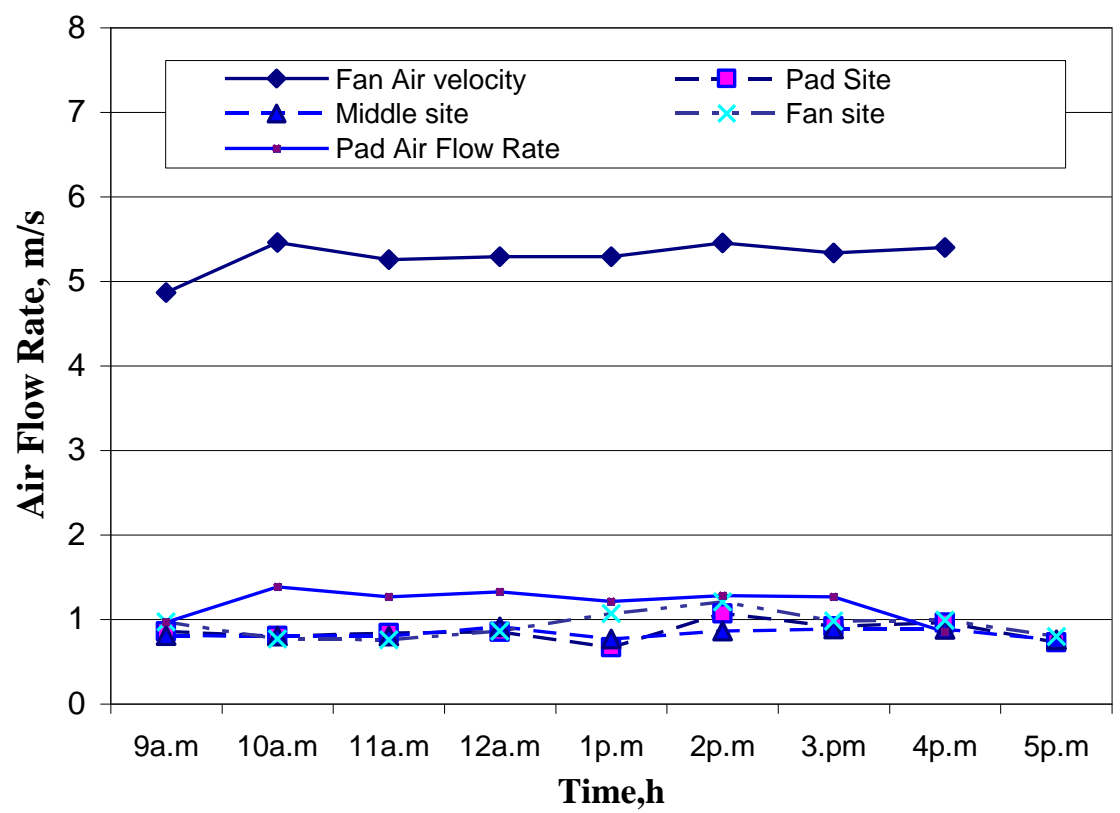

Fig. (13). Average air flow rate in ventilated greenhouse.

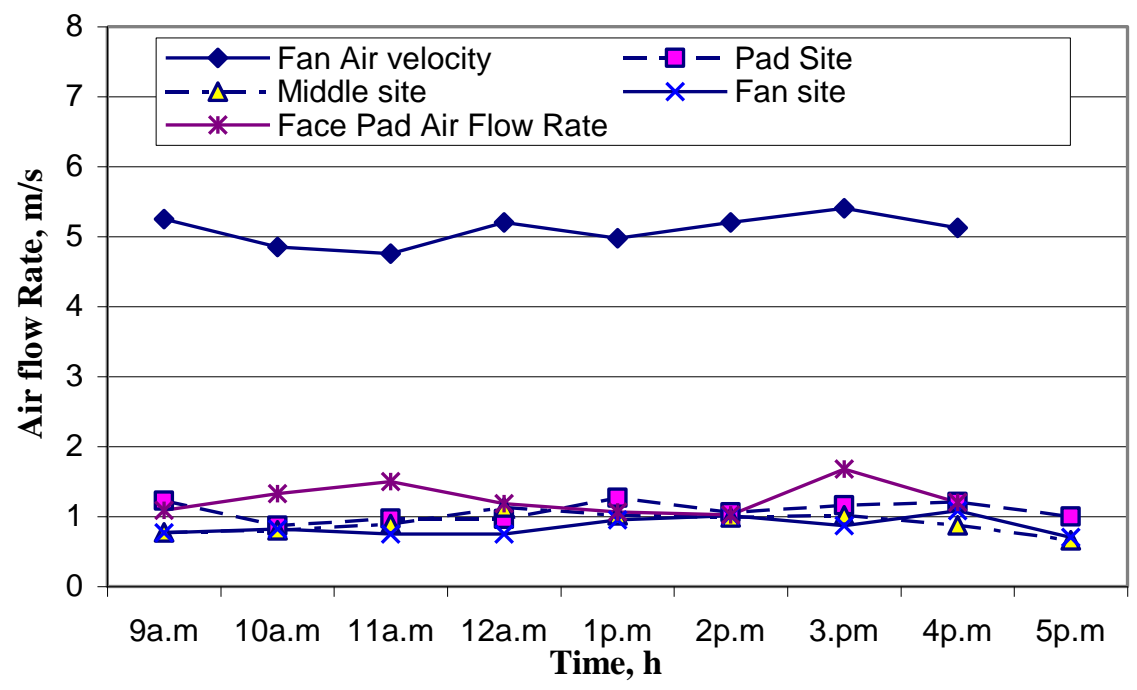

Fig. (14). Average air flow rate in cooled greenhouse. 
Fig. (15) reveal the variations between measured dry-bulb temperature and predicted dry-bulb temperature $\left(\mathrm{T}_{\text {in }}\right)$ in (Equation 4$)$. The average predicted dry-bulb temperature was close to the measurement temperature with $\pm 2.7 \%$ error percentage.

Regression analyses showed linear relationship $(\mathrm{R}=0.93$ in hot days 8,9 and 10 July, 2008) and the best fit relating predicted dry-bulb temperature in side the fiberglass greenhouse is

$$
\mathrm{T}_{\text {in }}=0.7914 \mathrm{~T}_{\text {measurement }}+7.0043 \text {. }
$$

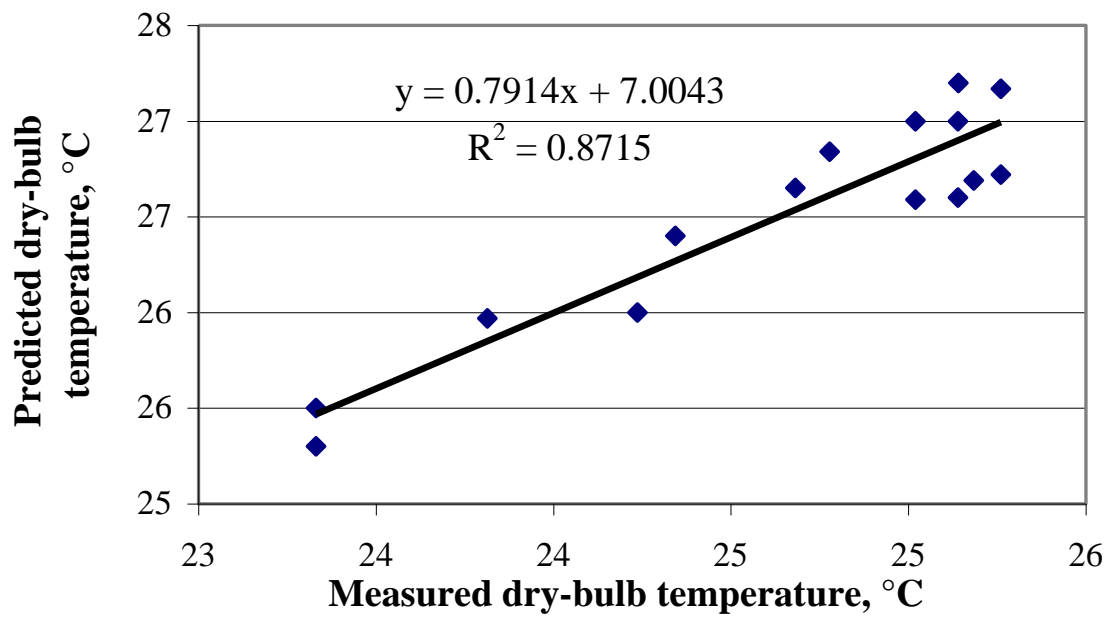

Fig. (15) Average predicted and measurement temperature for cooled fiberglass greenhouse July, 2008.

Figures (16 and 17) show the sensible heat in the first half (from pad to middle) and the second half (from middle to the fan) in fiberglass greenhouse from 9 a.m to 5 p.m for the two days (April 3 and 10, 2008). 


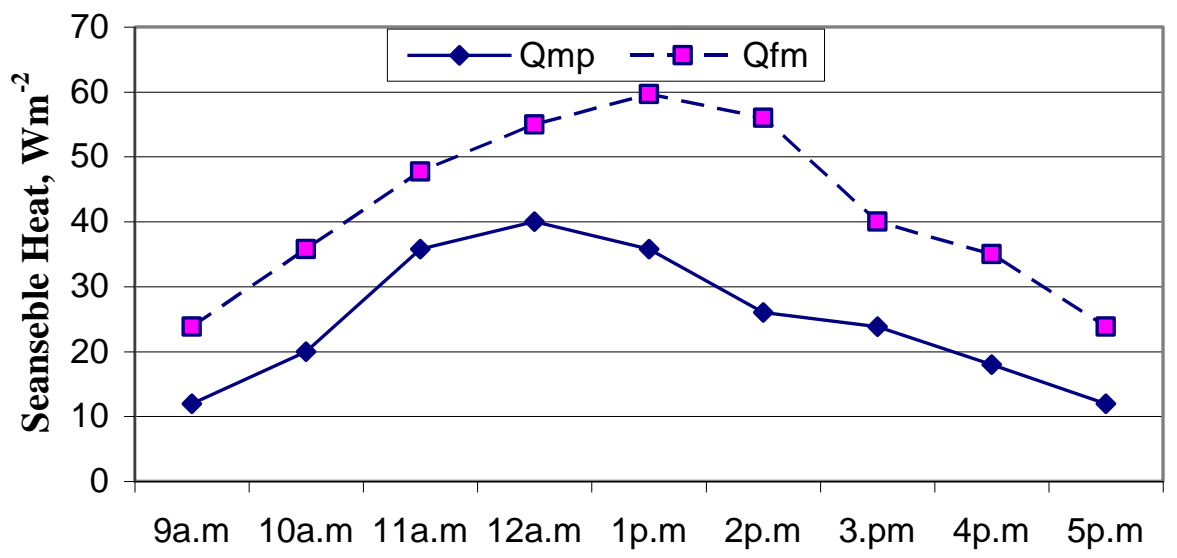

Time, $h$

Fig. (16). Sensible heat at first and second half of fiberglass cooled greenhouse, April 3, 2008.

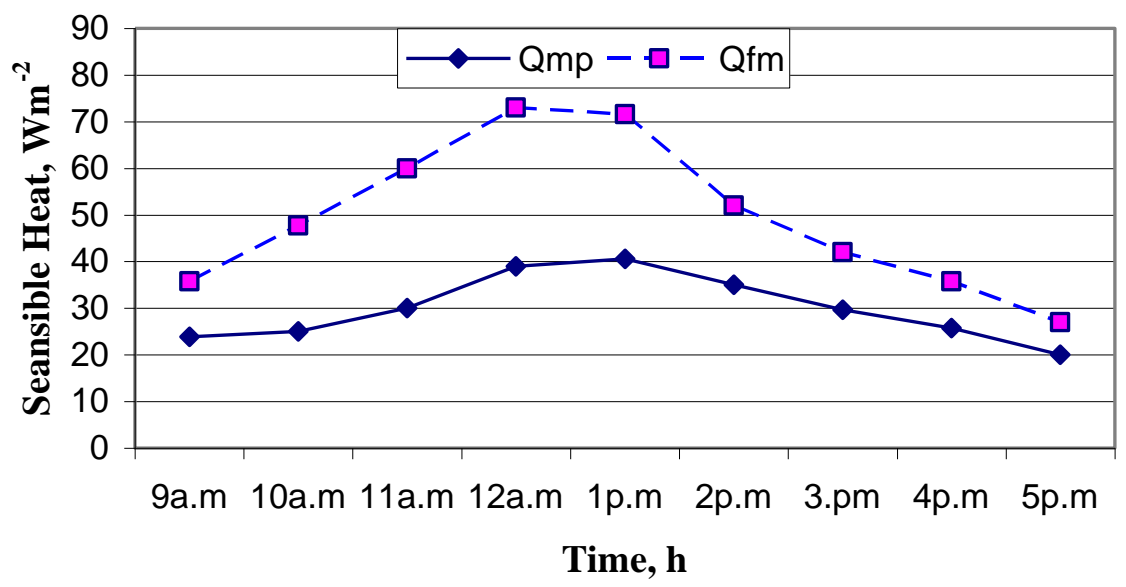

Fig. (17). Sensible heat at first and second half of fiberglass cooled greenhouse, April 10, 2008.

The heat exchanger simple model is applied for the greenhouse was able to predict the sensible heat transfers occurring inside the greenhouse volume between the fresh air delivered by the pads and the plants and soil irradiated by the sun. 


\section{The Steady-State Mass Balance}

Fig. (18) illustrates the mass balance in the greenhouse. From fig. (19) the rate of water vapor is produced within the space ranged between 0.007 $0.036 \mathrm{~kg} / \mathrm{s}$. The air density inside the greenhouse was $1.15 \mathrm{~kg} / \mathrm{m}^{3}$ and air density outside the greenhouse was $1.22 \mathrm{~kg} / \mathrm{m}^{3}$.

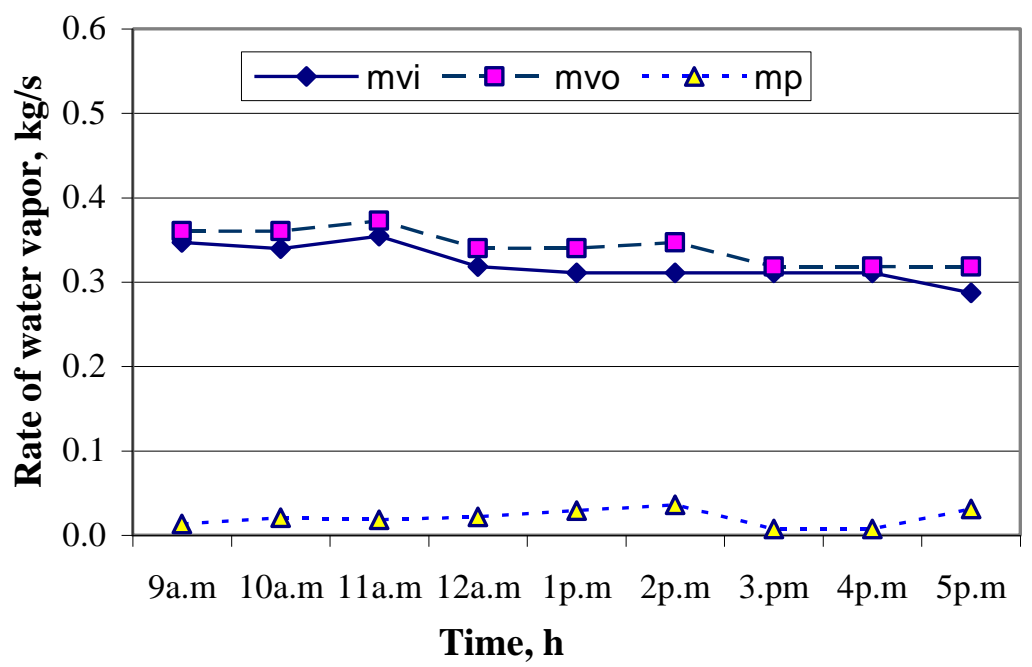

Fig. (18). The rate of water vapor carried out and inlet the airspace, and the rate of water vapor produced within the space, July 9, 2008.

\section{CONCLUSIONS}

Study the performance of evaporative cooling using pad-fan system operating in greenhouses under steady-state conditions is achieved. Also predicted dry-bulb temperature and air relative humidity inside the greenhouses through proposed model is illustrated.

Dr-bulb temperature and air relative humidity distribution was uniformly inside the greenhouse due to optimum structure design (structure, cover 
material and greenhouse orientation) and air velocity and appropriate pad area.

The average predicted dry-bulb temperature was close to the measurement temperature with $\pm 2.7 \%$ error Average.

It can be noticed; also the same trend when compared measured values of air relative humidity with the predicted one with $\pm 3.19 \%$ error average.

Moreover, sensible heat production inside greenhouses is calculated and compared for the two half's of it (the first half and the second one). The obtained data show that sensible heat production increased in the second half of greenhouse (far away from pad system). This increase was due to increasing in the air relative humidity and decreasing in evaporative pad system efficiency. 


\section{REFERENCES}

Albright, L. D. 1990. Environment Control for Animals and Plants. An ASABE Textbook No. 4. American Society of Agricultural and Biological Engineers. 2950 Niles Road, St. Joseph, MI. 49859659.USA.

ASHRAE. 1983. Evaporative Air-cooling Equipment. Chapter 4. Equipment Handbook. American Society of Heating, Refrigeration and Air-Conditioning Engineers. Atlanta, Georgia, USA.

Hanan, J.J. 1998. Greenhouse Advanced Technology for Protected Horticulture. Textbook. CRC Press. Bosa Raton, Boston, USA.

Kittas, C., T. Brtzanas and A. Jaffrin. 2001. Greenhouse evaporative cooling: measurement and data analysis. Transactions of the ASAE No. 44 Vol. (3) : 683-689.

Kittas, C., T. Brtzanas and A. Jaffrin. 2003. Temperature gradients in a partially shaded large greenhouse equipped with evaporative cooling pads, Biosystems Engineering. No. 85 Vol.(1) : 87-94.

Montero, J. I. and A. Antón. 1994. Greenhouse cooling during warm periods. Acta Horticulturae. International Society for Horticultural Science (ISHS) No.357 : 49-60.

http://www.actahort.org/books/357/357 4.htm

April 12, 2006.

Pollet, I. V. and J. G. Pieters. 2000 (a). Condensation and radiation transmittance of greenhouse cladding materials. Part 2: Results or a condensation cycle, Journal of Agricultural Engineering Research. Vol.(75) : 65-72.

Pollet, I. V. and J. G. Pieters. 2000 (b). Condensation and radiation transmittance of greenhouse cladding materials, Part3: Results glass plates and plastic films. Journal of Agricultural Engineering Research. No. 77 Vol. (4): 419- 428.

Psychometric Calculation program. Sugar Engineers' Library.

http://www.sugartech.co.za/psychro/index.php July 10, 2008.

Reda, E. A. 2005. The effect of reducing the solar intensity on the greenhouse thermal performance under semi arid climate. PH.D. Thesis. Agriculture Engineering Dept., Faculty of Agriculture, Ain Shams University.

Misr J. Ag. Eng., October 2008 
ـ حسن، أ. أ. 999 أ. تكنولوجيـا الزر اعـات المحميـة ـ المكتبـة الأكاديميـة ـ شـارع التحريـر -

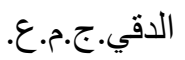

\section{الملخص العربي}

تحقيق الإتزان الحراري والرطوبي لنظام التبريد التبخيري داخل الصوب

خالد محمد عبدالباري

\section{كملات محمود مرسي}

\section{Iمدد هاشم حاتمI}

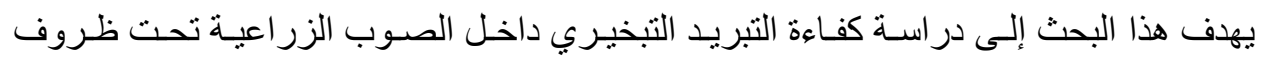

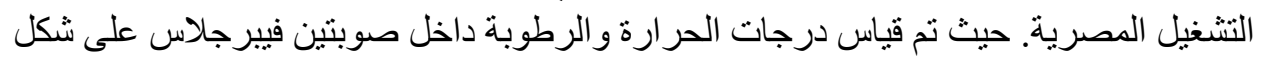

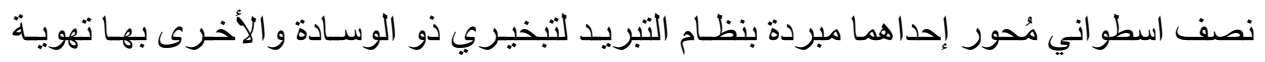
فقط.

تم تسجيل درجات الحر ارة الجافة والرطبة في ثلاثة نقاط داخل الصـوبتين (أمسام الوسـادة، وسط الصاء

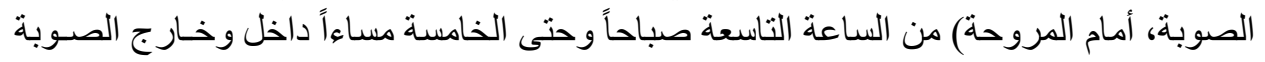
وقد تم حساب الرطوبة النسبية وكفاءة التبريد التبخيري.

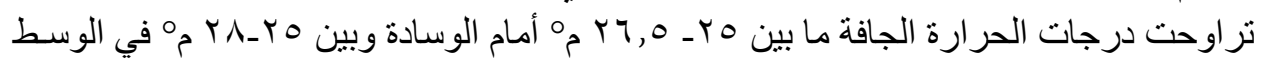

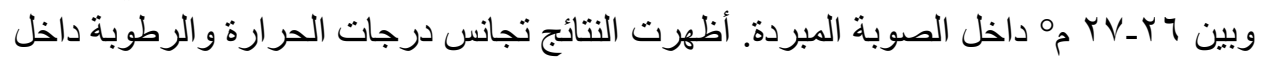

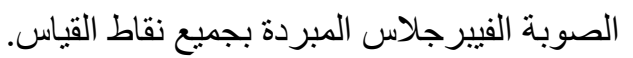

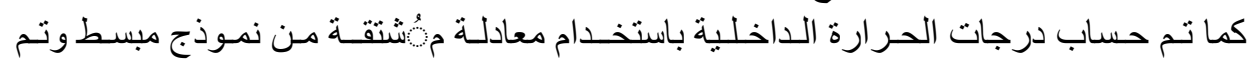

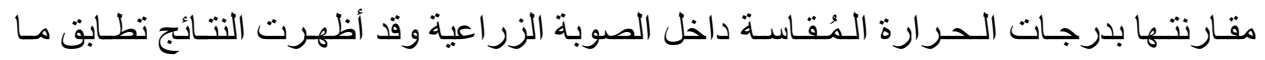

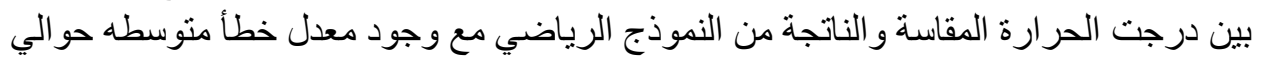
$\% \vee{ }^{\circ} \pm$

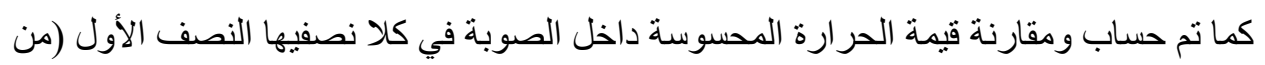

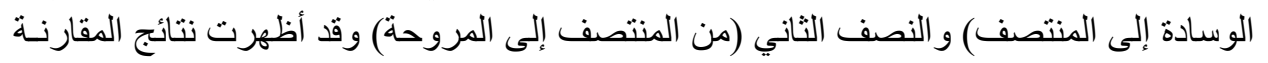

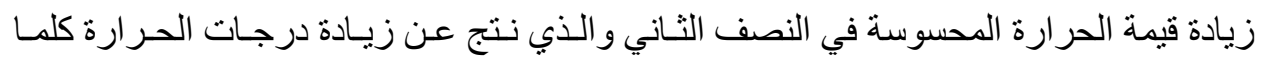
ابتعدنا عن الوسادة نتيجة انخفاض الرطوبة النسبية وانخفاض تأثير نظام التبريد التبخيري.

I أستاذ الهندسة الزر اعبةـ قسم الهندسة الزر اعيةـ كلية الزر اعة - جامعة القاهرة.

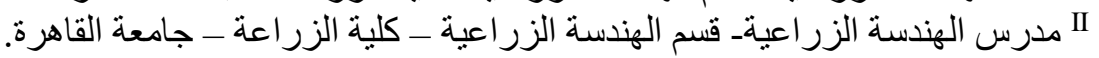

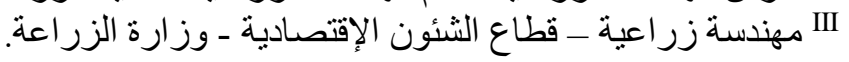

Misr J. Ag. Eng., October 2008 